\title{
Acknowledgments: Four Labyrinths
}

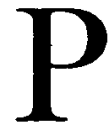

EOPLE who wander in mazes for twenty years need a lot of help along the way. But if labyrinths are icons of difficult process, by the same token they are occasions for generosity, and I have encountered more than my fair share of gracious guides. Pliny tells us that four labyrinths existed in ancient times. Taking up his clue, I thank those who have eased my passage through the four mazes I have experienced while imagining and then writing The Idea of the Labyrinth.

First came the magnificent, many-folded labyrinth of medieval studies, endlessly attractive precisely because of its multitudinous difficulties. It was probably Geoffrey Chaucer, English Daedalus "with his playes slye," who enticed me into this maze, but he had wily accomplices, not least the late R. W. Ackerman of Stanford University, who persuaded me to become a medievalist even though I had no interest in Old Norse. Classical and medieval mazes typically begin where they end and end where they began, as Boethius told Lady Philosophy; hence, appropriately, my point of entry into medieval studies, the origin of this book, and the final chapter all coincide in that brilliantly eclectic poem Chaucer's House of Fame, which is not only a beginning and ending but also an eccentric thread of Ariadne to the labyrinth of medieval literature. B. J. Whiting introduced me to the poem at Harvard University, where English 115 began with his wry line-by-line commentary. Although our approaches to Chaucer are fundamentally different, it was he who first revealed to me the charm of a work that has captivated me ever since and who inspired me to begin my own Chaucer courses with that poem. (It was while teaching The House of Fame to a group of baffled undergraduates in 1970 that $I$ hit upon the idea that the poem was itself a maze, only to realize how much was yet to be discovered about medieval 
labyrinths.) At Stanford, A. G. Rigg fed my addiction with impromptu soirées where a group of us read the poem aloud, stopping every few lines to explore one or another of the many paths branching out into other medieval texts and traditions. I never studied The House of Fame with V. A. Kolve, but his astonishing Chaucer seminars at Stanford persuaded me of the fruitfulness of looking for controlling metaphorswhat he would later call "narrative images"-in Chaucer's poetry. And while I never worked with the late E. Talbot Donaldson, his enthusiasm for my research on Chaucer and labyrinths alike of ten gave me confidence to forge ahead when I was weary.

All writers are necessarily implicated in three additional labyrinths. First, they are maze-treaders: as the English historian Ralph Higden complained, would-be scholars have to make their way through the labyrinths of invention - their material, their sources-before they can even begin to write. Second, they are maze-makers: as the rhetorician Geoffrey of Vinsauf reminds us, writers are architects, aspiring to design a well-crafted Daedalian domus. This is the labyrinth of disposition, of conceptual order. Third, the text itself is a labyrinth through which readers wander at will, comprehending all or nothing according to the mental fit between text and reader: as the preacher Robert of Basevorn warned, one man's artistry is another man's inexplicable maze. This is the labyrinth of words and of the reception of texts. Writers need help as they tread, create, and entangle others in mazes.

In the labyrinth of invention I encountered many tutelary spirits who directed me along unexplored pathways. Régine Astier, Christopher Baswell, Harry Bober, John Leyerle, Guy Lobrichon, Kathryn KerbyFulton, V. A. Kolve, Ruth Mellinkoff, Brian Stock, David Wallace, and Francis Woodman suggested references, answered questions, or found possible illustrations. Ann and Nollaig MacKenzie traveled to Cornwall to trace a labyrinth of whose existence I was uncertain. Colin Burrow, Terry Hoad, and Charlotte Morse retraced my steps for me when I was unable to do so myself and provided last-minute reference-checking in British libraries. Eleanor Silk, Yvon LePage, and Margaret F. Nims gave me liberal access to unpublished material. Ross Arthur, Christina Hawkes, A. G. Rigg, and Brian Stock helped interpret what I saw darkly in untranslated texts.

Readers of Umberto Eco's The Name of the Rose know that libraries, like texts, are labyrinths in their own right, and I am grateful to the guardians of such mazes for letting me explore hidden treasures at the British, Bodleian, and Cambridge University libraries and at many Oxford and Cambridge college libraries. The Library of the Pontifical Institute of Medieval Studies in Toronto continues to be the friendliest of labyrinths, and staff at York University Libraries were tireless in satisfying my Minotaurian gluttony for exotic interlibrary loans. 
Many people have played Saint Julian, patron of travelers and mazetreaders alike, on my behalf: I thank Ann Kussmaul, Paul and Elaine Hyams, Harriet Kirkley, and Mahmoud Manzalaoui for their hospitality in England on my various research trips. To Wendon Dobbs and Clive Evans, who generously let me and my labyrinthine obsessions invade their London home for many summers, I owe the deepest gratitude and affection.

One can neither explore nor build labyrinths without material support, and that I have had in abundance from the John Simon Guggenheim Foundation, the Social Sciences and Humanities Research Council of Canada, the Glendon College Research Grant Fund, and York University. Pliny thought the ancient labyrinths were a tremendous waste of resources, and I hope those who have invested enormously in this book feel their money has been somewhat better spent. Mazewalkers also need help in the exhausting tasks of searching bibliographies, checking dates and quotations, writing for permissions, photocopying articles, and so on. In this regard, I have been lucky in my talented and painstaking research assistants: Sheila Barry, Jinnean Bernard, Lucia Cino, Colleen Cowman, Nirmal Dass, Brandi Dickman, Patrick Johnson, Tom Klubi, Birgit Langwisch, and especially Dyan Elliott.

Would-be architects of a book like this one need special help in designing its complex groundplan, and I've been blessed with friends who helped me see the labyrinth whole. Judson Allen, John Leyerle, and Brian Stock played the roles of Ariadne and Daedalus, helping me chart the ground. Still more important, they believed in what I was doing even when I despaired of ever reaching the end. That this book exists at all is in large part due to their persistent encouragement over two decades.

If one needs an overview of the maze, one also needs distraction from its labors now and again. In this respect, I record my gratitude to my dear friend, the late Constantin Patsalas, who granted me the privilege of intense involvement in his own Daedalian artistry as a choreographer. His imagination sparked mine, and I of ten returned from rehearsals and excited discussions of his ballets with far greater energy to attack my own work. We had planned some day to collaborate on a ballet about the Cretan myth; his early death ended that hope.

People who create labyrinths need to gain perspective by stepping back and describing what they have designed so far. For letting me give papers and lectures on parts of this research over the years and for valuable feedback, I want to acknowledge Nicholas Mann (Oxford, 1975), Raymond St. Jacques and Douglas Wuertele (Universities of Ottawa and Carleton, 1981), John Leyerle (University of Toronto, 1982), Diana Theodores Taplin (University of Waterloo, 1982), Otto Gründler (International Congress of Medieval Studies, 1982, 1983, 1985, 1989), Patricia Brückmann ("Discovering in Wide Landscape," 1983), Thomas 
Hahn and Marjorie Woods (University of Rochester, 1984), the Dance History Scholars Association (1985), George Brown and Donald Howard (Stanford, 1985), and V. A. Kolve (Medieval Academy, 1988). A special award for patience in adversity must go to the generations of York University graduate and undergraduate students who, since 1970, have had versions of the chapters on The House of Fame and The Consolation of Philosophy inflicted on them, of ten at trying hours in the early morning.

Ancient labyrinths were lavishly decorated with works of art, and while my labyrinth of words is not as extensively ornamented as the mazes of Egypt or Etruria, I have been able to draw upon some supplemental visual artistry. Permission to reproduce photographs was graciously provided by the Bayerische Staatsbibliothek, Munich; the Biblioteca Apostolica Vaticana; the Bibliothèque Municipale, Dijon; the Bibliothèque Nationale, Paris; the Bodleian Library; the British Library; Her Majesty Queen Elizabeth II; Edwin H. Gardner; the Ghent University Library; the Laurentian Library, Florence; the Royal Commission on the Historical Monuments of England; the Soprintendenza Archeologica, Milan; and the Staatsbibliothek Preussicher Kulturbesitz, Berlin. Michel Baridon, William C. Irvine, and Leonard Boyle generously helped me obtain certain photographs, and Alison and Robert Ouellette provided expert assistance with other photographs and drawings. For dealing skillfully with the impact of the computer age on the generation and regeneration of textual mazes, I am grateful to Deirdre Maclean and Chris Monteith.

Once a verbal maze exists, its architect needs readers and listeners willing to venture inside and report on what they have seen. Many friends and colleagues have cheerfully traced various versions and segments of my labyrinthine text, and the book's present form owes a great deal to their comments; if those comments sometimes contradicted one another, that's what labyrinthine paradox is all about, and my task as architect has been to try to find some comprehensive if not transcendent resolution. I thank these courageous readers: Judson Allen, Ross Arthur, John Brückmann, Jane Couchman, Talbot Donaldson, Rachel Jacoff, Christopher Kleinhenz, Charlotte Morse, Glending Olson, Thomas L. Reed, Jr., David Staines, Brian Stock, Janet Warner, and Marjorie Woods. For suggesting unexplored by-ways and better paths after I thought my work completed, I am grateful to the readers so ably chosen by Bernhard Kendler of Cornell University Press: Christopher Baswell, James Miller, Hope Weissman, and Winthrop Wetherbee. Roger Haydon of the Press suggested appropriate finishing touches. While the manuscript has been much improved by the advice of all these fellow travelers, the academic enterprise remains an irrevocably multicursal maze in which I have sometimes insisted on my own way despite the wisdom of my guides. If errors remain, as they surely do, they go with 
the territory. Indeed, errors define the territory-without errores, there's no labyrinth.

My greatest debt is to my husband, Graham Parker, who accompanied me to countless labyrinth sites, tolerated recurrent crises of confidence, and lugged innumerable books back and forth from libraries during the years I was embroiled in the impenetrable labyrinths of administrative office. More important, he read one draft after another, providing the judicious perspective that only a highly literate nonspecialist can give. Having endured the countless labors, errors, false turnings, and blind alleys I have brought upon him in the course of writing this book, he has staunchly remained my center and my path.

Penelope Reed Doob

Toronto, Canada 
